\title{
On The Preferences of Principals and Agents
}

\author{
Marco Castillo* \\ Georgia Institute of Technology \\ Ragan Petrie \\ Georgia State University \\ Maximo Torero \\ International Food Policy Research Institute
}

December 2007

\begin{abstract}
One of the reasons why market economies are able to thrive is that they exploit the willingness of entrepreneurs to take risks that laborers might prefer to avoid. Markets work because they remunerate good judgement and punish mistakes. Indeed, modern contract theory is based on the assumption that principals are less risk averse than agents. We investigate if the risk preferences of entrepreneurs are different from those of laborers by implementing experiments with a random sample of the population in a fast-growing, small-manufacturing, economic cluster. As assumed by theory, we find that entrepreneurs are more likely to take risks than hired managers. These results are robust to the inclusion of a series of controls. This lends support to the idea that risk preferences are an important determinant of selection into occupations. Finally, our lotteries are good predictors of financial decisions, thus giving support to the external validity of our risk measures and experimental methods.
\end{abstract}

* This work was completed while Castillo and Petrie were on leave at University of Pittsburgh. We are grateful to Lise Vesterlund and the Economics Department for their hospitality and to Lise Vesterlund for her helpful comments. 


\section{Introduction}

A basic intuition in economics is that trade is not possible without heterogeneity of preferences or assets and that markets are best equipped to allocate resources and abilities to tasks. This paper takes this intuition to task by looking at risk. We investigate if risk preferences are heterogeneous in the field and if markets allocate people to tasks based on their risk preferences. We do this by implementing an artefactual field experiment (Harrison and List, 2004) on a random sample of managers in a fast-growing economic cluster.

The idea that markets need agents that are willing to take risks in order to develop dates back, at least, to Cantillon (1732). Later authors, like Knight (1921) and Hayek (1969), note that entrepreneurs are needed to bear any extra gains and losses from the efficient allocation of resources. However, there is no universal agreement that entrepreneurs must be willing to bear more risks. Schumpeter (1950), for instance, argues that, as markets develop, it is financial systems that should bear risks and not particular agents. However, in the presence of information asymmetries, there is no guarantee that financial markets will be able to absorb all risk. Perhaps the area of economics where the role of risk preferences is most explicit is that of contract theory. Standard treatments of the principal-agent model (Kreps, 1990) show that principals are able to offer incentive-compatible contracts that exploit the relative risk aversion of principals and agents. In this paper, we empirically investigate this asymmetry of risk.

There is little empirical evidence corroborating the basic assumption that principals are less risk averse than agents. Previous work has used hypothetical risky investment questions or situational questions to measure risk, and comparisons have been across the general population and across various sectors. The evidence is mixed. In early work, using mailed surveys to assess risk propensity, Brockhaus (1980) and Masters and Meier (1988) find no differ- 
ence between owners and managers. Cramer, Hartog, Jonker and Van Praag (2002) find a link between an ex-post hypothetical lottery risk measure and entrepreneurial choice at some previous point in a person's life, however, they caution that their results are not causal. Ekelund, Johansson, Jarvelin and Lichtermann (2005) use a psychological measure of "fear of uncertainty" to measure risk. They find a direct link between their risk measure and being self-employed. More generally, Bonin, Dohmen, Falk, Huffman and Sunde (2006) use a hypothetical risky investment question to measure risk and find a correlation between risk and variance in earnings across occupations.

A challenge in testing the hypothesis of heterogeneity of preferences is that we rarely observe people in these conditions. To wit, it is not clear that simple comparisons between people in managerial and non-managerial positions will provide the appropriate contrast. Indeed, those in managerial positions are likely to be more educated but otherwise similar to others. Also, relating variance in income and risk aversion across various sectors may pick up unexplained variation in wages across sectors that may be correlated with risk.

To avoid these problems, we collect experimental data on risk preferences in a random sample of managers of micro-enterprises in a fast-growing economic cluster. All firms in this cluster are involved in small manufacturing and are geographically close. We exploit the fact that many firms in this sector are managed by owners (entrepreneurs), but many others are managed by agents. Owner-managers and agent-managers face similar risks and market conditions. Moreover, in this context, business activity takes place with limited financial intermediation, so one expects risk preferences to be important. All this makes our sample ideal to compare the preferences of entrepreneurs with that of agents. If people select into activities according to their preferences, we should expect that those managing their own enterprises will be less risk averse than agents.

Indeed, we find strong evidence that agents are more risk averse than 
owners as theory suggests. In our experiments, agent-managers are more conservative in paid lotteries over gains as well as in lotteries over gains and losses. We test if our results are robust to the inclusion of covariate data, and we find that our basic result changes little. People sort into activities according to risk preferences. Moreover, we find evidence that experimental data correlates with important financial decisions. This provides evidence of the usefulness of experimental methods in understanding basic economic hypotheses and also of the importance of carefully selecting samples to make these hypotheses testable.

The paper is organized as follows. Section 2 discusses the sample and experimental methods. Section 3 presents basic experimental results and its relationship with economic decisions. Section 4 concludes.

\section{Sample Selection and Design}

The study was conducted in Gamarra, a fast-growing economic cluster in Lima, Peru. Gamarra is akin to the Garment District in New York; it is a sector full of firms involved in small-scale manufacturing and trade. Most of Gamarra's entrepreneurs are migrants that started their business outside the formal financial system. Until the early nineties, this sector has faced little regulation or support, making it a unique laboratory of how market forces work. $^{1}$

Gamarra is a 12-square block area in Lima, Peru. It emerged in the 1960 's as an area where migrants started small textile businesses to supply the growing garment industry. Since its inception, the area has attracted migrants and entrepreneurs for its agglomeration economies. Now, the area hosts thousands of small firms engaged in small manufacturing (i.e. retail, consumption and wholesale goods) and trade. Because of their small size, firms are capable of quickly adapting production to the needs of the market.

\footnotetext{
${ }^{1}$ In 1995, a new simplified tax system was implemented to make it possible for small business to pay taxes. Further modifications were introduced in 2003.
} 
This make the area dynamic and attractive to those willing to take risks.

In order to secure a random sample of the population of businesses, first, a pre-census of all establishments was conducted. Then, a random sample of establishments was selected. The manager of the establishment was surveyed on the characteristics of the firm. This survey collected information on the assets, age, size and financial matters as well as informal business networks. A separate, extensive survey was conducted to gather information on the manager's household. As part of the household survey, the manager was asked a few lotteries questions. These lotteries were only asked of managers, many of whom were owners of the firm as well. The experimental procedures are explained further below.

Table 1 presents a summary of the population of managers and firms. The data are restricted to firms managed by men because, of the 360 firms interviewed, only 47 were managed by women. Also, of the firms managed by women, $91 \%$ are also owners. Because of the small variation in agents and owners among women, we focus our analysis on the male-managed firms. All the results in the paper hold, however, if women are included. ${ }^{2}$

Looking at Table 1, sixty percent of firms are managed by their owners. Eighty-eight percent of managers are married, 85 percent finished high school and 23 percent have a college degree. The average age is 43 years. The table shows that the households of managers are not rich by Peruvian standards, where average, annual per-capita income at the time of the study was 18,000 soles. They are not poor either. They have an annual per capita income three times higher than the poverty line of 6.6 soles a day. ${ }^{3}$

\footnotetext{
${ }^{2}$ One notable difference between men and women is their risk aversion. Women are more risk loving than men. This issue, however, is addressed in another paper (Castillo, Petrie, Torero, 2007).

${ }^{3}$ Two dollars a day ( 6.6 soles) is one poverty line measure. This income equates to around 2,400 soles a year at the time of the survey (US\$1 $=3.3$ soles).
} 


\section{Table 1. Descriptive Statistics - Gamarra - Means}

$$
\begin{gathered}
\text { Managers } \\
\text { Owner (percent) } \\
\text { Married (percent) } \\
\text { High School (percent) } \\
\text { College (percent) } \\
\text { Age (years) }
\end{gathered}
$$$$
\text { Annual Per Cap. Income (,000) - soles }
$$$$
\text { Annual Per Cap. Inc. - Owner (,000) - soles }
$$$$
\text { Annual Per Cap. Inc. - Non Owner (,000) - soles }
$$$$
\text { Household Size }
$$

\section{Firms}

Number of Workers

Age of Firm (years)

Monthly Income $(, 000)$ - soles

Profit (percent)

Total Capital $(, 000)$ - soles
$60.38(3.0)$

$88.45(5.0)$

$84.98(2.0)$

$23.32(2.0)$

$43.40(0.68)$

$8.89(0.62)$

$9.76(0.97)$

$7.57(0.54)$

$3.89(0.10)$

$3.31(0.14)$

$15.30(0.67)$

$61.74(6.74)$

$49.32(9.70)$

$\frac{\text { Observations }}{\text { standard errors in parentheses, exchange rate }(3.3 \text { soles=US\$1) }}$

The average size of the firm is 3.3 members, with a maximum size of 26 in our sample. Most firms are relative young, 5.1 years old on average, with the youngest being less than a year and the oldest being 32 years old. The firms have an average income slightly below US\$5000 per year and the value of assets is around US\$14,000. In an typical month, the average profit per firm is 62 cent per dollar.

To elicit risk preferences, all managers were asked to respond to a series of simple lotteries. The lotteries are a simplified version of the lotteries first used by Binswanger (1980). Managers were asked to choose one of five risky prospects that gave a high and low payoff with equal probability. The lotteries are listed in Table 2 . They were constructed by either adding $30 \times k$ or subtracting $10 \times k, k=1, \ldots, 4$, to an initial high and low payoff 
of $(50,50)$ or $(0,0)$. The first set of lotteries therefore were over gains and the second over gains and losses. The units of the lottery were cents of the local currency. ${ }^{4}$ Managers made their decision over gains, then over gains and losses. Lotteries were resolved by flipping a coin. Managers were paid in cash the sum of their earnings from the gain and gain-loss lotteries.

\section{Results}

\subsection{Basic Results}

This section discusses the results of our experiment. Table 2 presents the frequency with which each lottery was chosen and the average decisions made according to several socio-economic variables. Forty-nine managers did not answer the lottery question. There does not appear to be selection on observables. While richer households are more likely answer the lottery question, owners are no more likely than non-owners to answer. There are no other differences (i.e. by age, education, etc.).

The top panel of Table 2 shows that choices are distributed evenly in the lottery over gains. The lottery over gains and losses, however, generates a significantly larger proportion of safe choices. ${ }^{5}$ The significant increase in risk aversion in the lotteries over gains and losses is as pronounced as the shift towards safe bets reported by Binswanger (1980, 1981) and Holt and Laury (2002) in lotteries with large stakes versus lotteries with small stakes.

That behavior across lotteries varies in an intuitive way gives us confidence that subjects took them seriously despite the small stakes. This would seem to be at odds with the assumption that the utility function for money is arbitrarily close to linear over small amounts of money. However, Holt and Laury (2002) show significant evidence of risk aversion even when lotteries use small stakes and that risk aversion increases as payoffs are scaled up.

\footnotetext{
${ }^{4}$ One hundred cents, or 1 sol, could buy a person lunch in Gamarra.

${ }^{5}$ The $\chi^{2}(4)$ test of difference in distributions is 39.34 ( $\mathrm{p}$-value $<0.000$ ).
} 
They also show that it is possible to find evidence of risk aversion over small stakes without implying impossibly high levels of risk aversion over large stakes.

Table 2. Experimental Data

Distribution of Choices

\begin{tabular}{cccc}
\hline \multicolumn{2}{c}{ Gains } & \multicolumn{2}{c}{ Gains E Losses } \\
\hline High \&3 Low Payoff & Frequency & High \& Low Payoff & Frequency \\
$(50,50)$ & 18.56 & $(0,0)$ & 31.44 \\
$(80,40)$ & 23.86 & $(30,-10)$ & 29.19 \\
$(110,30)$ & 20.45 & $(60,-20)$ & 20.45 \\
$(140,20)$ & 18.18 & $(90,-30)$ & 13.26 \\
$(170,10)$ & 18.94 & $(120,-40)$ & 5.68 \\
Observations & 264 & Observations & 264
\end{tabular}

Average Responses

\begin{tabular}{ccccccc}
\hline & \multicolumn{4}{c}{ Gains } & \multicolumn{3}{c}{ Gains É Losses } \\
\hline Variable & No & Yes & t-test $(p$-value) & No & Yes & t-test $(p$-value $)$ \\
Owner & 2.70 & 3.12 & $-2.45(0.02)$ & 2.15 & 2.44 & $-1.93(0.05)$ \\
40 years or older & 2.96 & 2.94 & $0.11(0.91)$ & 2.45 & 2.21 & $1.60(0.11)$ \\
Above Median Income & 2.86 & 3.05 & $-1.11(0.27)$ & 2.23 & 2.42 & $-1.22(0.22)$ \\
High School & 2.48 & 3.04 & $-2.37(0.02)$ & 2.03 & 2.38 & $-1.72(0.09)$ \\
\hline
\end{tabular}

Also, our lotteries provide a direct test of the hypothesis of constant absolute risk aversion. By design, the payoffs of both lotteries differ only by a constant (50). The definition of constant absolute risk aversion implies, therefore, we should not expect any change in behavior across lotteries. We conclude then that managers possess either decreasing absolute risk aversion or suffer from loss aversion. ${ }^{6}$

The second panel of Table 2 compares risk preferences across different segments of the population of managers. The first 3 columns of the bottom panel present comparisons for the lotteries over gains and the last 3 columns

\footnotetext{
${ }^{6}$ Given the small stakes of our lotteries, the hypothesis of loss aversion seems more plausible.
} 
present comparisons for the lotteries over gains and losses. We find that owners are significantly less risk averse than managers. This is true in both lotteries. On average, the decision of an owner-manager is 19 percent higher than of an agent-manager. While we find differences across other populations, evidence on other personal or household characteristics is less robust.

Table 3 presents regression analysis of individual decisions. The availability of survey data on managers and their households allow us to test whether the difference in behavior is just a reflection of different socio-economic backgrounds. Since choices are ordered by risk, we use an ordered logit regression. The regressions control for education, age, income, family size and a polychoric index (Angeles and Kolenikov, 2004) of household assets and durable goods. The results are unchanged if additional controls are added or if we control by type of business (i.e. retail, consumption, or wholesale). ${ }^{7}$

Table 3 confirms that the effect of ownership remains even when controlling for additional covariates. Our results suggest that entrepreneurs are different from other managers. Even controlling for income and wealth, owners than manage their own firms are significantly less risk averse than managers who do the same job but for others. This is remarkable given that our sampling procedure eliminates many of the potential confounding effects by holding occupation and market conditions constant. Our results are important because they confirm economists' fundamental views of markets and social interactions. Entrepreneurs are more tolerant to risk and agents are more risk averse than principals.

\footnotetext{
${ }^{7}$ For instance, the results are similar if we add controls for experience and household age composition among others.
} 
Table 3. Ordered Logit Regressions on Lottery Choices

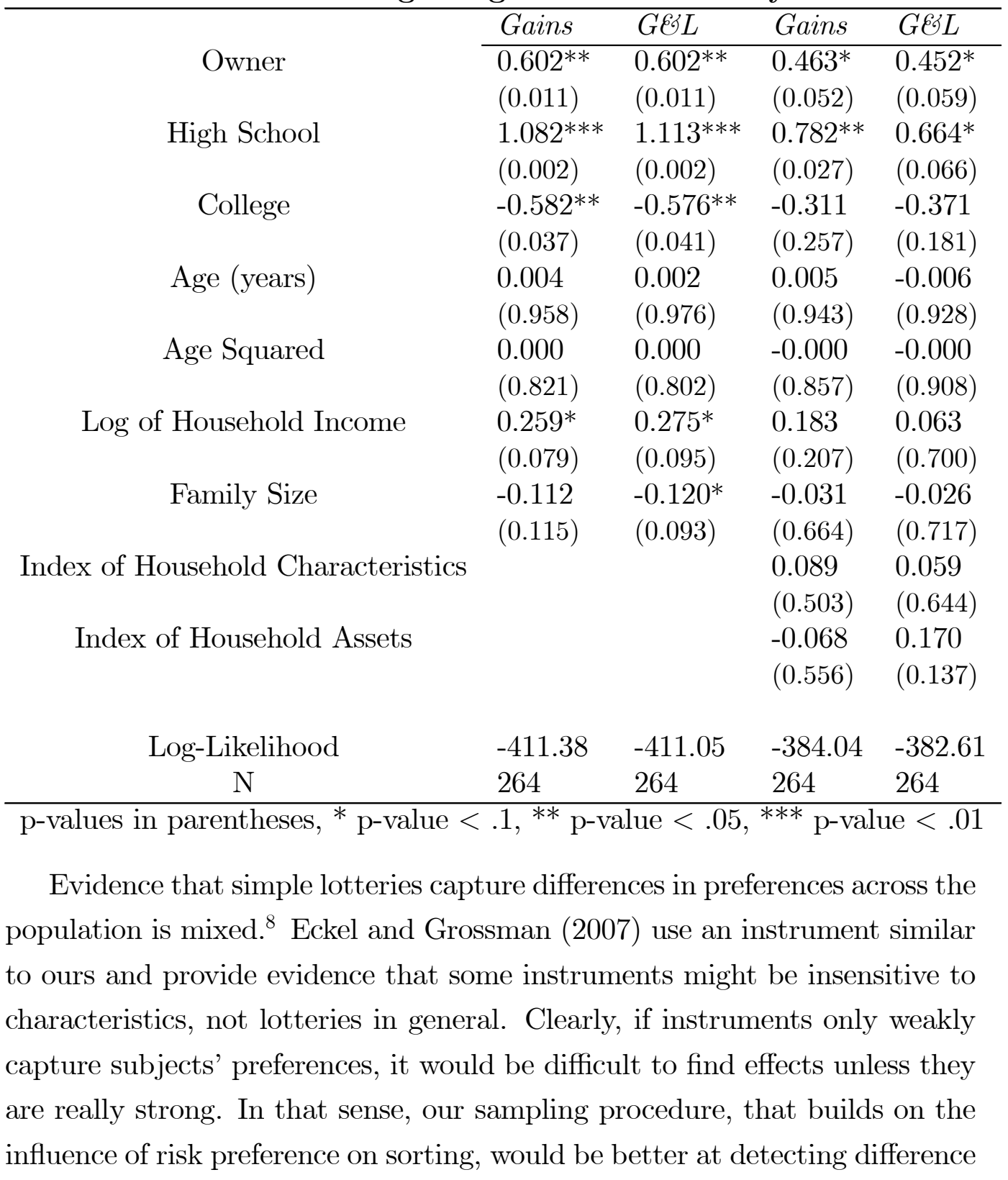

\footnotetext{
${ }^{8}$ For instance, Holt and Laury (2002) find that risk aversion is weakly related or not at all with gender, major, or race. Dave, Eckel, Johnson and Rojas (2007) find a correlation between several risk measures and gender. Dohmen, Falk, Huffman, Schupp and Wagner (2005) find correlations between risk lotteries and gender, age and height. For an excellent review of the literature on risk and gender, see Croson and Gneezy (2007).
} 
in the population.

We would also like to know if risk preferences elicited with lotteries and actual economic outcomes are correlated. The evidence from the literature is mixed. Some have found a correlation. For example, Binswanger $(1980,1981)$ finds agricultural investment decisions related to risk measures. Jacobson and Petrie (2007) find no correlation between household savings decisions and risk measures. We speculate that these inconclusive results may be due to the types of decisions (i.e. household versus business) to which these risk preferences are being related. In the next section, we look at the correlation between our risk measures and household and business decisions.

\subsection{Risk Preferences and Economic Decisions}

A potential concern is that experimental data, while strongly correlated with personal characteristics, is uncorrelated with important economic decisions. ${ }^{9}$ Table 4 presents Tobit regressions on the amount saved and on the amount of loans held. The first decision is a household financial decision, and the second is a firm financial decision. All regressions control for household and firm characteristics and for whether the manager is the owner or not. Finally, we include the decisions made by the manager in either the lottery over gains or the lottery over gains and losses.

We find that while decisions in the experiments are weakly and insignificantly correlated with household savings, lotteries are positively and significantly correlated with the amount of credit held by the firm. This result is to be expected since household decisions are not solely a function of the manager's preferences but, potentially, also of other household members' preferences. Credit decisions, on the other hand, are under the control of managers. This result reassures us of the external validity of experimental methods and that our measures actually explain decisions. We have already

\footnotetext{
${ }^{9}$ Of course, preferences may not be correlated with economic decisions because of heterogeneous expectations. We do not explore that here.
} 
established that risk preference are partially captured by being an owner. So, the effect measured in this regression is likely to underestimate the total effect of risk preferences on economic decisions. 
Table 4. Tobit Regressions on Financial Decisions

\begin{tabular}{|c|c|c|c|c|}
\hline & \multicolumn{2}{|c|}{ Savings $(, 000)$} & \multicolumn{2}{|c|}{ Loans $(, 000)$} \\
\hline Choice in Gain Lottery & $\begin{array}{l}1.093 \\
(0.114)\end{array}$ & & $\begin{array}{l}1.069 \\
(0.254)\end{array}$ & \\
\hline Choice in Gain \& Loss Lottery & & $\begin{array}{l}0.293 \\
(0.703)\end{array}$ & & $\begin{array}{l}1.863^{*} \\
(0.065)\end{array}$ \\
\hline Owner & $\begin{array}{l}1.583 \\
(0.449)\end{array}$ & $\begin{array}{l}2.157 \\
(0.312)\end{array}$ & $\begin{array}{l}10.904^{* * *} \\
(0.001)\end{array}$ & $\begin{array}{l}10.702^{* * *} \\
(0.001)\end{array}$ \\
\hline High School & $\begin{array}{l}-0.566 \\
(0.864)\end{array}$ & $\begin{array}{l}-0.232 \\
(0.945)\end{array}$ & $\begin{array}{l}-4.149 \\
(0.257)\end{array}$ & $\begin{array}{l}-3.709 \\
(0.298)\end{array}$ \\
\hline College & $\begin{array}{l}2.460 \\
(0.247)\end{array}$ & $\begin{array}{l}1.938 \\
(0.369)\end{array}$ & $\begin{array}{l}4.087 \\
(0.181)\end{array}$ & $\begin{array}{l}3.847 \\
(0.199)\end{array}$ \\
\hline Age (years) & $\begin{array}{l}0.423 \\
(0.564)\end{array}$ & $\begin{array}{l}0.529 \\
(0.485)\end{array}$ & $\begin{array}{l}2.112^{* *} \\
(0.041)\end{array}$ & $\begin{array}{l}2.148^{* *} \\
(0.036)\end{array}$ \\
\hline Age Square & $\begin{array}{l}-0.007 \\
(0.393)\end{array}$ & $\begin{array}{l}-0.008 \\
(0.346)\end{array}$ & $\begin{array}{l}-0.024^{* *} \\
(0.036)\end{array}$ & $\begin{array}{l}-0.025^{* *} \\
(0.033)\end{array}$ \\
\hline Log of Household Income & $\begin{array}{l}1.534 \\
(0.265)\end{array}$ & $\begin{array}{l}1.809 \\
(0.205)\end{array}$ & $\begin{array}{l}4.556^{* *} \\
(0.020)\end{array}$ & $\begin{array}{l}4.765^{* *} \\
(0.014)\end{array}$ \\
\hline Family Size & $\begin{array}{l}-0.646 \\
(0.332)\end{array}$ & $\begin{array}{l}-0.807^{*} \\
(0.225)\end{array}$ & $\begin{array}{l}-0.230 \\
(0.782)\end{array}$ & $\begin{array}{l}-0.152 \\
(0.854)\end{array}$ \\
\hline Index of Household Characteristics & $\begin{array}{l}-1.734 \\
(0.132)\end{array}$ & $\begin{array}{c}-1.672 \\
(0.158)\end{array}$ & $\begin{array}{l}-0.003 \\
(0.998)\end{array}$ & $\begin{array}{l}-0.054 \\
(0.972)\end{array}$ \\
\hline Index of Household Assets & $\begin{array}{l}3.472^{* * *} \\
(0.000)\end{array}$ & $\begin{array}{l}3.489^{* * *} \\
(0.000)\end{array}$ & $\begin{array}{l}-1.807 \\
(0.187)\end{array}$ & $\begin{array}{l}-2.105 \\
(0.130)\end{array}$ \\
\hline Firm Age (Months) & $\begin{array}{c}-0.009 \\
(0.565)\end{array}$ & $\begin{array}{c}-0.007 \\
(0.639)\end{array}$ & $\begin{array}{l}-0.017 \\
(0.444)\end{array}$ & $\begin{array}{l}-0.014 \\
(0.502)\end{array}$ \\
\hline Number of Workers & $\begin{array}{l}0.545^{*} \\
(0.074)\end{array}$ & $\begin{array}{l}0.593^{*} \\
(0.061)\end{array}$ & $\begin{array}{l}0.247 \\
(0.566)\end{array}$ & $\begin{array}{l}0.197 \\
(0.644)\end{array}$ \\
\hline Firms is Registered & $\begin{array}{l}4.236 \\
(0.364)\end{array}$ & $\begin{array}{l}4.495 \\
(0.355)\end{array}$ & $\begin{array}{l}-3.479 \\
(0.415)\end{array}$ & $\begin{array}{l}-3.287 \\
(0.441)\end{array}$ \\
\hline Implicit Interest Rate (00) & $\begin{array}{l}0.662 \\
(0.753)\end{array}$ & $\begin{array}{l}0.800 \\
(0.712)\end{array}$ & $\begin{array}{l}0.222^{*} \\
0.077\end{array}$ & $\begin{array}{l}0.218^{*} \\
(0.078)\end{array}$ \\
\hline Constant & $\begin{array}{l}-38.731^{*} \\
(0.067)\end{array}$ & $\begin{array}{l}-42.225^{*} \\
(0.053)\end{array}$ & $\begin{array}{l}-105.684^{* * *} \\
(0.001)\end{array}$ & $\begin{array}{l}-110.779^{* * *} \\
(0.001)\end{array}$ \\
\hline Log-Likelihood & -158.68 & -159.86 & -266.96 & -265.86 \\
\hline Observations & 264 & 264 & 264 & 264 \\
\hline
\end{tabular}


The estimates indicate that, conditional on taking a loan, the marginal effect of one higher choice in the lottery over gains would double the amount of credit held by the firm. One higher choice in the lottery over gains and losses would triple the amount of credit held. This is true even controlling for personal and firm characteristics. ${ }^{10}$ This is important because our experiments not only detect important differences in the preferences of the population, but also identify statistically and economically significant consequence of risk preference on decisions. This suggests that previous results that show that risk experiments are either insensitive to preferences or uninformative about decision making might partially be due to the experimental instrument and sample choice. Indeed, the issue of heterogeneity of beliefs is less of a problem in our sample due to the fact that subjects in our experiment face similar market conditions.

\section{Conclusions}

We investigate whether risk preferences of economic agents are important in market economies and explain sorting into jobs. Using a simple experimental procedure, we measure risk preferences in a random sample of business managers. All the managers work in a dynamic small manufacturing cluster, share similar socio-economic backgrounds, face similar market conditions, but differ in their ownership of a business. Our design reduces many of the confounding effects encountered in other studies of risk and increases the external validity of our results.

We find two key results. First, managers that own the firm where they work are significantly less risk averse than managers that do not own the firm. This result is robust to the inclusion of socio-economic characteristics of managers and type of manufacturing. This supports the theoretical assumption that agents are more risk averse than principals. Second, our study

\footnotetext{
${ }^{10}$ Choices in the lotteries are correlated with other financial decisions like having participated in credit groups or holding credit cards.
} 
gives strong support to the basic economic intuition that entrepreneurs are different and markets encourage them to sort into activities that require dealing with significant risks. Our measures of risk aversion are correlated with business financial decisions made by the manager.

Our study gives support to the importance of field experiments, as articulated by Harrison and List (2004). Taking experimental methods to the population of interest and sampling from a population where confounding effects are less likely to be an issue seem to be important. Experimental methods can not only be a powerful tool to detect differences in preferences, but they can also detect evidence of sorting. The distribution of preferences across principals and agents in a business sector seems to be consistent with economic theory. 


\section{References}

Angeles, G and S. Kolenikov, The Use of Discrete Data in Principal Component Analysis: Theory, Simulations, and Applications to Socioeconomic Indices, working paper, Carolina Population Center, UNC, 2004.

Binswanger, Hans (1980), "Attitudes Toward Risk: Experimental Measurement in Rural India," American Journal of Agricultural Economics, 62, 395-407.

Binswanger, Hans (1981), "Attitudes Toward Risk: Theoretical Implications of an Experiment in Rural India," Economic Journal, 91, 867-890.

Bonin, Holger, Thomas Dohmen, Armin Falk, David Huffman and Uwe Sunde (2006), "Cross-Sectional Earnings Risk and Occupational Sorting: the Role of Risk Attitudes," IZA Working Paper 1930, Bonn, Germany.

Brockhaus, Robert (1980), "Risk-Taking Propensity of Entrepreneurs," Academy of Management Journal, 23(3), 509-520.

Cantillon, Richard (1732), Essai Sur la Nature du Commerce en General.

Castillo, Marco, Ragan Petrie, and Maximo Torero (2007), "Are Women More Risk Loving Than Men? Evidence from Entrepreneurs," Working Paper, Georgia Institute of Technology.

Cramer, J.S., J. Hartog, N. Jonker and C.M. Van Praag (2002), "Low Risk Aversion Encourages the Choice for Entrepreneurship: An Empirical Test of a Truism," Journal of Economic Behavior and Organization, 48, 2936 .

Croson, Rachel and Uri Gneezy (2007), "Gender Differences in Preferences," Journal of Economic Literature, forthcoming.

Dave, Chetan, Catherine Eckel, Cathleen Johnson, and Christian Rojas (2007), "On the Heterogeneity, Stability and Validity of Risk Preference Measures," Working Paper, University of Texas-Dallas.

Dohmen, Thomas, Armin Falk, David Huffman, Jurgen Schupp and Gert Wagner (2005), "Individual Risk Attitudes: New Evidence from a Large, 
Representative Experimentally Validated Survey," IZA Discussion Paper 1730, Bonn, Germany.

Eckel, Catherine and Philip Grossman (2007), "Forecasting Risk Attitudes: An Experimental Study Using Actual and Forecast Gamble Choices." Forthcoming, Journal of Economic Behavior and Organization.

Ekelund, Jesper, Edvard Johansson, Marjo-Riitta Jarvelin and Dirk Lichtermann (2005), "Self-Employment and Risk Aversion: Evidence from Psychological Test Data," Labour Economics, 12, 649-659.

Harrison, Glenn and John A. List (2004), "Field Experiments," Journal of Economic Literature, XLII, 1013-1059.

Hayek, Friedrich August von (1969), Individualism and Economic Order, Glencoe, Chicago: University of Chicago Press.

Holt, Charles, and Susan Laury (2002), "Risk Aversion and Incentive Effects," American Economic Review, 92 (5), 1644-1655.

Jacobson, Sarah and Ragan Petrie (2007), "Inconsistent Choices in Lottery Experiments: Evidence from Rwanda," EXCEN Working Paper 2007-03, Georgia State University.

Knight, Frank H. (1921), Risk, Uncertainty and Profit, Boston, MA: Hart, Schaffner \& Marx, Houghton Mifflin Company.

Kreps, David (1990), A Course in Microeconomic Theory, Princeton: Princeton University Press.

Masters, Robert and Robert Meier (1988), "Sex Differences and RiskTaking Propensity of Entrepreneurs," Journal of Small Business Management, 31-35.

Schumpeter, Joseph (1932), Capitalism, Socialism, and Democracy. New York: Harper Collins. 